A shorter version of this chapter has been published in Reid, Hazel and Linden West, eds. (2014) Constructing Narratives of Continuity and Change: A Transdisciplinary Approach to Researching Lives. London: Routledge. Parts of this chapter have appeared in Molly Andrews (2007) Shaping History: Narratives of Political Change. Cambridge: Cambridge University Press; Molly Andrews (2014) Narrative Imagination and

Everyday Life. New York: Oxford University Press; Centre for Narrative Research (2014) What Is Narrative Research. London: Bloomsbury Press.

Nesbitt-Larking, Paul, Catarina Kinnvall and Tereza Capelos, eds. (2014) The Palgrave Handbook of Global Political Psychology Palgrave Macmillan.

\title{
Narrating Moments of Political Change
}

\section{Molly Andrews}

'Every age has its stories'(1) Eric Selbin tells us, 'as does each individual, stories that shape and form the world we know...Stories essentially reflect the cultural values of their time and place as well of those who tell them' (Selbin, 2010: 24-25). Stories are the means by which individuals and communities make sense not only of their current existence, but of their pasts and futures, both real and imagined. It is through stories, shared and contested, that individuals and groups construct a sense of identity - who is 'us' and who is 'them'. The stories change over time, and even those that remain constant (on the printed page, for instance) change in their meaning and significance, to tellers and audiences alike.

As such, stories play a vital role, not only in constructing the political world as it is, but also as it might be, depicting how it once was. These stories are never consensual - it is the mark of humankind to contest the stories of other individuals and communities. But stories are one of the primary vehicles through which politics are articulated and debated.

Given that this is so, it is surprising that stories have only recently come in to focus as a legitimate vehicle for trying to understand the complexity of the political world, and of political change more specifically. In this chapter, I will discuss the growing interest in political narratives, and will offer one elaborated example to illustrate this discussion.

The opening decade of the twenty-first century has been marked by an increasing interest in what can broadly be termed 'political narratives' (Andrews, 2007; Davis, 2002;

Jackson, 2002; Polletta, 2006; Selbin, 2010; Tilly, 2002; Zingaro, 2009), a phenomenon which can perhaps be seen as one manifestation of the ballooning study of narrative more generally within the social sciences. Stories are one of the most effective tools that individuals and communities have for making sense of themselves and the world around them, and as such the study of the relationship between narrative and politics is vital. As Selbin (2011) writes: 
People rely on stories to make sense of their world, their place in it, and their (im)possibilities....stories reflect and refract people's lives in a way that almost no other text can, making the abstract concrete, the complex more manageable, and rendering matters 'real.' Stories reduce the immense complexity of the world, involv- ing our daily lives, to human-sized matters, adding information to stores that are already stocked, fitting by and large into familiar pathways.

(Selbin, 2010: 30)

While there is no strict consensus over what is and is not to be regarded as political narrative, there appears to be a general agreement that stories - both personal and communal - are pivotal to the way in which politics operates, both in people's minds (i.e. how they understand politics, and their place within and outside of the formal political sphere) as well as to how politics is practised. For a policy to be effective, there needs to be a reasonable story for why it is needed, or why another response would be inadequate or inappropriate. These stories, as it were, are not just within the domain of the individual, but are built upon the collective memory of a group, just as they help to create how that memory is mobilised and for what purposes. And critically, narratives are central to the machination of politics, for in constructing the stories about what is and isn't working, and how this compares to a notion of 'how it should be' we are invariably deciding what aspects of social/political/economic/cultural life are and are not relevant to the current problem and its solution - in other words, the lifeblood of politics. Thus, political narratives engage the imagination, not only in constructing stories about the past and the present, but in helping to articulate a vision of an alternative world. As Marqusee (2012) writes:

We need utopian thinking if we are to engage successfully in the critical battle over what is or is not possible, if we are to challenge what are presented as immutable 'economic realities.' Without a clear alternative - the outlines of a just and sustainable society - we are forced to accept our opponent's parameters.

(Marqusee, 2012: 10)

All of these stories - constructions of the past, present and future - only ever exist in relation to other stories, and politics is nothing if not a stage for competing stories to be told about the same phenomena.

Hammack and Pilecki open their chapter in this volume (see Chapter 5) with an extract from Bill Clinton's nomination of Barack Obama for re-election at the 2012 Democratic National Convention. Clinton, a most skilled orator, sets up a choice for those he addresses as 'my fellow Americans'. What kind of America do they want to live in? A 'winner-take-all' country or one in which 'we're-all-in-this-together'? Rhetorically, this is a very effective strategy; while Clinton does not tell a story as such, he does use a storied framework to make his points, and the key question that he raises here is one about the characters who will determine how the plot unfolds. In this way, Clinton instils in his audience a sense of agency; their actions will help to determine which way the story goes. Hammack and Pilecki argue that 'politics is in part a language game'. This 
chapter shares some of the basic premises upon which that argument is built, but the emphasis is slightly broader; rather than concentrating on linguistic devices, the focus is more on the function of story in the machinations of politics - one of the three traditions discussed by Hammack and Pilecki - or what I call 'political narratives'.

\section{What are political narratives?}

So what are political narratives? What do they actually look like, and how can we recognise them when we see them? Elsewhere, I have described political narratives as the 'stories people tell about how the world works, how they explain the engines of political change, and the role they see themselves, and those whom they regard as being part of their group, as playing in this ongoing struggle' (Andrews, 2007: 8). But the meaning of the term 'political narrative' is not limited to stories which are told or untold, lived, dreamed or imagined by individuals. Rather, it can also refer to a larger cluster of national stories, within which individuals position themselves, explicitly or otherwise. Discussion of political narratives always turns to an examination of the relationship between macro and micro narratives, in other words the relationship between the stories of individuals and the stories of the communities in which they live. Political narratives that individuals tell may or may not be explicitly about politics; often the most telling of them are not. But in the stories which they weave, individuals reveal how they position themselves within the communities that they live, to whom or what they see themselves as belonging to/alienated from, how they construct notions of power, and the processes by which such power is negotiated. For individuals, political narratives are the ligaments of identity, revealing how one constructs the boundaries of, and the connections between, the self and the other.

Hannah Arendt has argued that storytelling is 'the bridge by which we transform that which is private and individual into that which is public, and in this capacity, it is one of the key components of social life' (Arendt, 1958: 50). 'What makes mass society so difficult to bear is not the number of people involved, or at least not primarily, but the fact that the world between them has lost its power to gather them together, to relate and to separate them' (1958: 52-53). Political narratives are vital in establishing these relational bonds. However, one could also make an observation of the reverse trend; that is, one of the stumbling blocks to realising social change in modern times has been a tendency to over-personalise issues which should remain in the sphere of the public/political domain. Zingaro (2009) describes an 'emotional economy' in which there is an "offering up of "the real story" of trauma, pain, or humiliation, from someone who has "been there" '(Zingaro, 2009: 11). While such stories might be able to provide particular insight into difficult experiences, their telling depends upon the existence of a willing, listening audience. Knowledge which is 'too threatening or too different from the listener's experience' is suspect: 'A story without recognizable landmarks, or some measure of a familiar narrative trajectory, marks the teller as lying, or possibly exaggerating' (Zingaro, 2009: 11). Stories always exist in relation to other stories, of individuals and communi- ties, and they rely upon these bonds in order to be 'tell-able'. Political stories, even when they relate to individual experience, are never just the property of isolated selves. 
Stories which can be told, be they political or otherwise, are always predominantly the terrain of individuals, but all persons are ultimately part of wider social networks. Thus, while it is individuals who remember or forget, it is communities that heavily influence what is deemed memorable or forgettable. Examples of these abound - as people recall their memories of learning of the assassination of John F. Kennedy, or their encounters with the global Occupy movement. But equally, people engage in political storytelling on numerous occasions that do not appear to have anything to do with politics, at least not overtly so. If by politics one means the negotiation of power, then a significant number of stories could be classified, broadly, as political narratives.

Macro political narratives, in contrast, refer to the 'cultural stock of plots' (Polletta, 2006: 10 ), in other words the contexts that make some stories more tell-able than others. Although sometimes these are explicitly articulated, in history textbooks, or in addresses made by public officials marking certain events, they derive much of their impact from the fact that often they are simply taken-for-granted. So, passing through Trafalgar Square in the centre of London, one does not need to know the details of the Battle of Trafalgar to be able to recognise that it must be an important piece of the story Britain tells itself about who it has been, and the outstanding contributions of certain of its citizens. And in 2003, what more iconic moment marked the fall of Saddam Hussein than when his statue was attacked in Baghdad's main square?

The term 'political narratives' often refers to the dynamic movement between individuals and wider social contexts, or, in the words of C. Wright Mills, between biography and history. When Marx asserted that people make history, but not in circumstances of their own choosing, he was remarking upon this fundamental relationship between the micro and macro units of analysis, which ultimately lead to one another. And like the river running to the sea, it is not possible to discern the demarcation between the two. While each of us may deem ourselves as special or unique in some ways - and surely, we hope, at least in the eyes of our family or loved ones - still we recognise that there is nothing that we ever do that is not located within a wider social web of relationships, and all of these within the complex matrices of social structures. Equally, there is nothing of politics that exists independent of identifiable human beings. One does not need to embrace the cult of the individual to recognise that even those persons who are known to us only through the media have private thoughts, desires and relation- ships. For instance, one would not be able to understand the actions of militant suffragette Emily Davison as she threw herself under the King's horse at the Epsom Derby in 1913 without contextualisation; her suicide would be meaningless in the absence of the broader movement. And while a social movement is always bigger than the sum of its individual members, it is nonetheless comprised of real people with real lives. Sometimes their individual stories, and sacrifices, become transformed into a symbol of the movement. 


\section{What do political narratives do?}

In the life of individuals and of the community, political narratives play a number of key functions. In times of traumatic rupture, the construc- tion of a story about the past can be regarded as the first and most critical step in moving out of the darkness. This is the basic premise upon which some truth commissions have been established. The Truth and Reconciliation Commission of South Africa attempted to piece together a 'tell-able past' through the collection of more than 22,000 personal nar- ratives in which individuals recounted what abuses they and their loved ones had suffered during key moments in the apartheid era (specifically between the Soweto massacre of 1961 and the first democratic election in 1994). Desmond Tutu, who chaired the TRC, commented at the first victim hearing:

We pray that all those people who have been injured in either body or spirit may receive healing through the work of this com- mission...We are charged to unearth the truth about our dark past. To lay the ghosts of that past, so that they will not return to haunt us and that we will hereby contribute to the healing of a traumatized and wounded people.

(cited in Field, 2006: 32)

Central to the construction of the TRC was that storytelling, even about horrific events, could perform a healing function, if not for individuals, then at least for communities who must now find a way to live together.

Though the actual act of narrating a painful past may cause additional suffering, it is also true that finding commonality with the stories of others can itself bring a measure of satisfaction, even agency; 'The presence of others who see what we see and hear what we hear assures us of the reality of the world and ourselves' (Arendt, 1958: 50). Political narratives play a critical role in creating and recreating history - at the level of the individual, the community, and the nation. Political narratives help to establish the framework through which communities make sense of themselves, and their dynamic nature is such that the past is never really past, but is rather a site of ongoing battle. As Dienstag comments:

Debates over the meaning of history cannot be exorcised from politics... Whoever abandons work on memory to others may find themselves imprisoned by the results ... Human beings fight over his- tory because they conceive their pasts to be an essential part of who they are. And they are right.

(1997: 206)

Political narratives are, then, a key mechanism through which the past is reformulated in light of a desired future.

Political narratives are strategically employed in the construction of national identity. Through the use of political narratives, we tell our- selves and others who we are (and as 
observed above, these stories change over time). These are the hardships we have endured; these are the principles for which we stand; these are rewards that we as a people have procured. Our group identity claims rest upon our stories. And these stories are then represented in a myriad of ways, including public celebrations, memorialisation, and in history lessons.

National narratives are not synonymous with political narratives, though there is a significant overlap between them. Not all political narratives concern matters of the nation, and many national narratives are about culture, or art, for instance. While politics encompasses the broad spectrum of stories about power - who has it; how it is shared or abused; and the particular contexts that inform its various manifestations - national narratives are concerned with those negotiations which hap- pen explicitly around questions of the nation. Questions of national identity are invariably linked to national narratives. Nations are com- munities, both real and imagined, and from the time they are very young, people develop a sense of what it means to be from this place, a sense of belonging and/or alienation, an evaluation of how things run, who has control over what, and how that control is exercised. National narratives are both general (this is who we are as a people) and specific (this is what it means to me to be from here), and are manifest in both formal and informal ways. National identity can be expressed either in a formal, public context (such as the statues, national holidays, and his- tory books mentioned above), but also in more informal ways, through routine cultural practices and in the daily talk of ordinary people, as they reveal the complexities, contradictions, and passions of what this identity means to them as situated individuals and groups.

\section{Political narratives and social change}

As has already been made clear, political narratives come in many different hues, but amongst the most important of these - and the focus of the remainder of this chapter - are those that relate to social change. Stories are a critical engine behind the machinations of change, as they demand a temporal sequencing that will build from the past - thus the struggle over history - be anchored in struggles of the day, but will be driven by a vision for an alternative future. Let us examine this in greater detail.

These narratives can be important in terms of igniting political aware- ness, leading ultimately to political engagement. Critically, there is a potentially powerful relationship between telling and becoming, or narration and agency. Although it is not always so, the articulation of an experience of marginalisation into a public narrative form can contribute to a building of a group consciousness. Having access to the stories of other persons with whom one shares life circumstances, there exists a possibility that one can see oneself in the stories of others, and as a consequence, reduce the often-paralyzing sense of alienation. The recognition that 'I am not alone' can be accompanied by the birth, or the expansion, of a politicised group consciousness.

There is then a strong relationship between narration and agency, at the level of the individual but also in the wider culture. As Jens Brockmeier writes: 'Narratives are 
capable of extending the symbolic space which a culture unfolds at a certain point in history' (2009: 207). Stories once formulated can begin to change things, the very telling helping to shift what is tell-able. And these stories, critically, are not only about the world as it is or has been, but also about how it might be (either for the better, or worse) and as such function as a clarion for action. Here the function of the narrative imagination is vital, helping individuals and communities to envision other possible worlds.

\section{Making sense of political narratives}

Thus far I have discussed the meaning and function of political narratives in the abstract. I would now like to turn my attention to focus on three political narratives in order to flesh out some of the ideas I have presented here. The first example will be the most extensive, and will be followed by two shorter examples. Although the first two examples come from my own research - the first in East Germany, the second in Great Britain - the third relates to one of the most iconic political moments in political life of the United States in the twentieth century, and sheds new light on a well-worn tale.

First, a word of background. In 1992 I conducted a study with a number of key East German activists who had played an important role leading up to the events of 1989. One of the questions I asked my participants was how they reacted to the opening of the Berlin Wall, on 9 November 1989. Like all persons living in the West, I had seen images splattered across the media of people drunk with happiness, dancing on the wall, champagne popping everywhere. And yet the accounts of those days that I heard told a very different tale.

A powerful example of this is the account given to me by Reinhard Weißhuhn, an East German who had been part of the small under- ground opposition in his country for more than 20 years, beginning in the 1970s. The interview takes place in the front room of his flat, which is situated 200 meters from the border between East and West Germany. Here he describes how he experienced the opening of the wall, and the psychological challenges this posed for him:

On the way home [at about 10:30 pm] I noticed many people all running into the same direction...they were all running to the end of the world...the street was full of cars and one could hardly walk at all...I then walked with the stream and got to the border crossing, Bonnholmer Strasse ... which was the first crossing to be opened. Two hundred meters from here. It was so crammed full with people you couldn't move. And everybody was pushing through the crossing. The policemen were just standing around, they didn't know what to do and were completely puzzled. I asked a few people...what was happening. Of course, I know, I could see, but I didn't actually, I didn't understand. And I stood there for about a half hour in this crowd and then went home and switched the television on. Then I watched everything on television, transmissions from everywhere, Ku'damm and all other border crossings. And I could see that peo- ple were coming over, that is as seen from the west.... I was totally paralysed...all this continued for the next 
few days and it took me a whole week before I went across, Potsdammer Str. It is difficult to describe...this was such a very elementary transformation of one's existence, of ... the whole world in a way.

Weißhuhn's description of how he learned of the opening of the wall is interesting for several reasons. First, it is clear that although he was active in the opposition movement, he, like others, was surprised by what he encountered as he returned home that November evening. While in retrospect it is possible to identify the signs of imminent demise that now seem so clear, it is important to remember that only ten months before the fall of the wall, in January 1989, Honecker defiantly pronounced 'The Wall will still stand in fifty and also in a hundred years', and on 7 October of that same year, the date marking the 40th anniversary of the creation of the country, he again expressed his belief in the future of the country, even in the face of evident growing dis- quiet. 'Socialism will be halted in its course neither by ox, nor ass' he proclaimed. It was only one month later that Weißhuhn encountered so many people running 'to the end of the world' - that is to say, to the world that lay on the other side of the wall. In Weißhuhn's account, first he followed the flow of the people, until he arrived at the border crossing, the wall. There he stood for a half hour, trying to take in what he observed. The policemen stood around, not knowing what to do, and Weißhuhn himself struggled to make sense of what he saw but could not understand. Ultimately, he returned to his own home, and watched the events through the lens of West German televi- sion. From this mirrored perspective, the crowds poured in, rather than rushed out.

But the effect of witnessing these events, even from the once-removed position that Weißhuhn tried to adopt, is paralytic for him. He cannot join the crowds, but neither can he resist travelling across the border. Weißhuhn then elaborates on his response to the opening of the wall. Here one can see that his explanation is framed by his perception of me as someone from outside of the two Germanies. He describes to me in detail the geography of the corner of Berlin upon which his psychological transformation was played out:

I'll try to explain. I have lived...I have been in Berlin since '73 and I have always lived two hundred meters from the wall. And this wall, to me, has become a symbol of captivity in every respect, also in a metaphoric, symbolic sense. And this is what I have been ramming my head against for the last twenty years. And I had, as a way of survival, I had resolved to ignore this wall as far as I could...And I tried to do the same throughout the week, when the wall had gone. I did not only try to suppress the fact that the wall had been there previously, but I also tried to suppress the fact that it had gone. And it didn't work. When I went across the wall for the first time, I did so at Potsdamer Platz, where there hadn't been a crossing, they had only torn a hole, simply torn a hole into the wall, yes. And that's where I wanted to go through, precisely there. I walked through like a sleepwalker. I could not conceive of the idea up to the moment when I was through, that that was possible. Well, and then I stood for a very long time over at the other side in noman's land, and could not move forward or backwards. And then I cried, I was totally overwhelmed. 
For Weißhuhn, it was important that he cross the border not where there was a clear opening, such as Bonnholmer Strasse where he had seen the masses cross on the night of 9 November, but rather at Potsdamer Platz, where a hole had been torn into the wall. Somehow this hole contained within it more evidence of the struggle that had led to these events. A number of respondents with whom I spoke mentioned to me the difficulty of accepting that the wall, which had symbolised the strength of the repression of the people, could be disbanded so suddenly and so totally. To what extent had its strength merely existed in the eyes of those whose lives it restrained?

As a political narrative, the one that Weißhuhn offers here is extremely powerful. Let us examine it by posing some basic questions of who, what, where, when, and why.

The first question is 'who'. The speaker, as already stated, is one of a handful of persons who had been engaged in the East German under- ground opposition movement. He is clearly not one of the people who were dancing on the wall on the night it opened. And he is telling his story to a real outsider, an American psychologist who sits with a West German translator in his living room, who is unquestionably interested in his story. Weißhuhn's account is also peppered with other people: those who he encountered at Bornholmerstrasse, pushing to get through (who could also be some of the same people who were pop- ping champagne later in the night), and of course the very intriguing policemen - 'standing around, completely puzzled' - who were already sensing that they had lost their role and for whom life would soon become unrecognisable.

The 'what' of the story is its content - what did this opposition activist do on the night the Berlin wall opened, and the days following this event. He is telling this story because that focus has been suggested by me, the interviewer. Weißhuhn offers an identity narrative, through depicting a series of response to the opening of the wall that reveals the complexity of his emotional response to the events as they unfolded. Careful attention must be paid not only to what is being said, but what is not being said. This story, though of one individuals' experience, belongs to a larger stock of stories, those about the opening of the Berlin Wall. He does not need to say to me that the opening of the wall was a critical moment both in terms of his own biography and in terms of historical change. Neither does he need to tell me that the experiences of many East Germans on this night were very different from his own.

The spatial question of where permeates the account. Throughout the telling, Weißhuhn infuses his story with a very precise sense of place, or rather places. First, there is Bornholmerstrasse, which has the dual func- tion of both the street that he lives on, and also the first place where the wall was opened. Second, there is his living room, where he not only retreated the night of 9 November 1989, but also where our inter- view is taking place. Third, there is the Ku'damm, West Berlin's answer to New York's Fifth Avenue. As he sits in his apartment watching West German television, East Germans on the Ku'damm are visually pouring in to his living room, even as in reality, they are exiting East German, from a place that is less than 200 metres away. And finally, there is Potsdammer Platz, an area of Berlin that would see one of the greatest transformations in the years to come but which at that time had only a small hole in the concrete wall that allowed access to the west. 
Weißhuhn offers a very precise temporal framing for this account. In response to a question that asks about a specific night, his initial movement locates his story even more specifically, at a particular hour on that most particular night. He stays at the border crossing for about a half-hour, and then returns home. The next week in this account is a bit of a haze. What is remarkable here is that it takes him a full week to bring himself to be able to cross over in to the West. The narrative itself fits completely within this temporal frame. However, it must be remembered that it is me as the researcher who has also assisted in this framing: not only do I pose a question about a particular night, but when I write about it, I choose where to begin and end the extract. In fact Weißhuhn said much before and after this story, so my role in its framing is not insignificant. There are other dimensions of temporality that are present: when Weißhuhn is speaking to me, the year is 1992, about two and half years after the events he describes. By this time, much had already changed; Germany had been 'reunified', and East Germany was no longer in existence. Those political activists, like Weißhuhn, who had spearheaded political change in the GDR had very different roles in their transformed country. Finally, at the time of this writing, more than 20 years have passed since Weißhuhn told me this story in 1992. In fact he is involved in a follow-up study I am doing with many of the same people I interviewed in 1992. He still lives on Bornholmerstrasse, and our most recent interview took place in the very same living room in which we had spoken 20 years earlier.

Why did Weißhuhn tell me this particular story? Perhaps a prior ques- tion is why did I ask him what he did on that night; after all, he told me this story in response to my question, though obviously there are different versions of the same experience which he could have offered.

I was interested in personal experiences of this heightened moment as one lens that could offer insight in to the relationship between micro and macro stories. This story is a powerful story of 'the opening of the wall'. When put in to the context of other stories of this event, it offers a distinct counter-narrative. And if one wishes to understand the deep emotional impact that this political event had on Weißhuhn, one must first try to comprehend the experience of living inside the wall.

We turn now to our second example. The extract that follows comes from an interview with Rose Kerrigan, one of the founding members of the Communist Party of Great Britain in the early part of the twentieth century. I interviewed Kerrigan in the mid-1980s (Andrews, 1991/2008), and asked her about her earliest engagement in political activity. Kerrigan began by describing the poverty in which and others lived in Glasgow in the early 1900s.

I remember as early as seven or eight years of age, and thinking that it was very odd that here were so many people who could afford to be dressed up. We lived around the corner from the Royal Theatre ... we used to go down and watch them go into the theatre from the taxis and wonder...here we could hardly buy our own shoes. That made me feel that there was something wrong, somewhere. Why did these people not share their money with us? . . I never felt anger and I never felt envy. I just felt it was wrong somehow....at 12 years old I took part in the 1915 rents strike in Glasgow. [when Rose tried to convince her mother to withhold the 
extra rent] she said 'we'll run into debt and we'll never be able to get out of it'. I said to her 'you give the extra money to me and I'll bank it.' Then when I saw I couldn't convince her by myself I went up the whole close which was 16 ten- ants and got them all agreed to withhold the rent and we never ever paid that increase. When the rent-man came for the rent, we paid the rent but we never paid the increase ... . The result was the 1915 Rent Restriction Act which lasted till 1957. There weren't increased rents.

This excerpt, with its rich detail, provides much for one who is inter- ested in political narratives: Kerrigan's perception of her young self; the importance of relative deprivation and responses to perception of social inequality; challenging ideas of childhood and political efficacy; and the nuts and bolts of the birth of an effective social movement.

Freeman argues that 'narratives, as sense-making tools, inevitably do things - for people, for social institutions, for culture, and more' (2002: 9). A critical question is what this story actually accomplishes. Why does Rose Kerrigan tell it? This story positions the young Rose as someone who not only perceived injustice, but who acted to fight against it. Even at the age of 12, she was someone who put her principles in to action (something which would continue to be a cornerstone of her identify for the next seven decades). Neither was she someone who would shy away from authority, be they the landlord, her mother, or others in years to come.

Rose situates the story of her youth in a very particular setting. Living around the corner from Glasgow's Theatre Royal, she and her siblings would watch people as they arrived at the theatre in taxis. The affluence of others was especially marked in comparison to the economic hard- ship that her family and her neighbours knew. 'Why did these people not share their money with us' she asks. One can hear in these words the seeds of a socialist consciousness. Rose portrays herself as someone who is not envious or angry, but simply fair-minded. She emphasises time and again that the disparity in wealth was simply wrong.

The construction of the child activist makes a particularly strong impression. Effective activism is always impressive, but it is especially so if that person is not even yet in their teenage years. That she would organise the rest of the close into collective resistance speaks volumes for the importance of small actions. This story derives some of its impact from the retrospective knowledge of the role of the Glasgow Rent Strike of 1915, in which 30,000 people eventually withheld their rent from profiteering landlords.

Let us turn now to our third and final example. The extract comes from an interview with Rosa Parks, who became famous around the world as the woman who, in 1955, refused to go to the back of the bus because of the colour of her skin. This small, defiant act kicked off the Montgomery Bus Boycott, a critical moment in the explosion of the civil rights movement in the United States. Popular folklore has it that Parks was almost an unknowing actor, tired and weary on entry to the bus, and spontaneous in her refusal. That she was the secretary of the Montgomery chapter of the NAACP is not so well known, nor that she had been selected to perform this challenge. But listening to her account of this event puts the 1955 encounter with the bus driver, James Blaike, in 
another perspective. She recalls:

About 12 years before this, about 1942, this same driver had evicted me from his bus for refusing to hand him my fare and then get off of the bus and go around and try to find my way back in the busy by the rear door. Because I refused to do that, he evicted me from the bus. He didn't call the policemen that time. He just told me I couldn't ride his bus. I told him I was already on the bus, and I didn't see any need of getting off and going around to the back door to try to get in, but that was one of the things he demanded. It was the very same driver, because I never did forget his face from that time on. I don't think he remembered me at the time I was arrested.

(Parks in Wigginton, 1992: 233)

This small passage raises a number of questions for the reader, and a scrutiny of it begins to demonstrate the power of political narratives, which specific focus on three elements: Time and timing; agency; and the intersection of biography and history.

First, the question of time is critical here. Parks alerts her listener to the fact that not only was the refusal in 1955 not her first, but it was not even her first with this bus driver. Indeed, they had already performed their respective roles, though not in an identical fashion, more than a decade earlier. If we take seriously Parks' claim that she had done this before, than we immediately question the myth of her as unknowing actor. This leads us to the second point.

Second, in Parks' account, she is a very active agent in her own des- tiny. In 1942, she speaks back to the driver who demands her eviction. Although she departs from the bus, she is not 'finished' with him, as history will tell us.

Third, this story, interesting though it is, derives at least some of its impact from the knowledge that we as readers have, that Parks could not have had in either 1942 or even 1955, that this action lit a powder keg of political resistance. There is no school child in the United States who does not know the name of Parks, and in 2005, she died a national hero, the first woman ever to be granted the posthumous honour of lying in state in the US Capitol Rotunda.

In all three examples, the speakers offer accounts that help to shed light on wider social and political processes. All of the speakers position themselves as knowing actors in a heated political contest. The accounts themselves add texture and invite further reflection on key political events, the opening of the Berlin Wall, the Glasgow Rent Strike, and the Montgomery Bus Boycott. 


\section{Closing remarks}

Selbin concludes his book on social change and the power of stories by asking his readers:

Sometimes there is a passion or a quality harder to describe but which you have undoubtedly experienced when you have talked with someone who has been involved in acts of resistance, rebellion or revolution...How does one articulate to a stranger, an acquain- tance, even a friend or loved one, a matter at once so complex and so simple?

(Selbin, 2010: 193)

In this chapter I have tried to offer a framework that will assist in making sense of political narratives which are 'at once so complex and so simple'. Reinhard Weißhuhn's detailed account about his experiences of the opening of the Berlin Wall is a particularly compelling example of the power of political narratives. In order to make sense of what is being said, the reader must make the linkages between the micro and the macro narrative, between Weißhuhn's personal biography and momentous historical change. He presents a story of the age in which he lives, but also a story about living in these times. And through a close reading of his very personal account, we too come to understand much more about the effects and the meaning of political change. 


\section{Note}

1. In this chapter, I will use the term 'story' and 'narrative' interchangeably, recognising that there are others who would caution against so doing.

\section{References}

Andrews, M. (1991/ re-issued 2008) Lifetimes of Commitment: Aging, Politics, Psychology. Cambridge: Cambridge University Press.

Andrews, M. (2007) Shaping History: Narratives of Political Change. Cambridge: Cambridge University Press.

Andrews, M. (2014) Narrative Imagination and Everyday Life. New York: Oxford University Press.

Arendt, H. (1958) The Human Condition. Chicago: University of Chicago Press. Brockmeier, J. (2009) 'Reaching for meaning: Human agency and the narrative

imagination'. Theory and Psychology, 19 (2): 213-233.Centre for Narrative Research (2014) What is Narrative Research. London:

Bloomsbury Press.Davis, J. ed. (2002) Stories of Change: Narrative and Social Movements. Albany, NY: SUNY Press.Dienstag, J. F. (1997) 'Dancing in Chains': Narrative and Memory in Political Theory.

Stanford, CA: Stanford University Press.Field, S. (2006) 'Beyond "healing”: Trauma, oral history and regeneration.' Oral History, 34 (1): 31-42.

Freeman, M. (2002) 'The Presence of What is Missing: Memory, Poetry and the Ride Home'. In: Pellegrini, R. J. and Sarbin, T. R. eds. Critical Incident Narratives in the Development of Men's Lives. New York: Haworth Clinical Practice Press.

Jackson, M. (2002) The Politics of Storytelling; Violence, Transgression and Intersubjectivity. Denmark: Museum Tusculanum Press.

Marqusee, M. (2012) 'Let's Talk Utopia'. In: Bradshaw, Ross, ed. Utopia. London: Five Leaves Publications.

Polletta, F. (2006) It was Like a Fever: Storytelling in Protest and Politics. Chicago: University of Chicago Press.

Reid, Hazel and Linden West, eds. (2014) Constructing Narratives of Continuity and Change: A Transdisciplinary Approach to Researching Lives. London: Routledge. Selbin, E. (2010) Revolution, Rebellion, Resistance: The Power of Story. London: Zed

Books Ltd.Tilly, C. (2002) Stories, Identities, and Political Change. Lanham, MD: Rowman and

Littlefied Publishers Inc.Wigginton, E. ed. (1992) Refuse to Stand Silently By: An Oral History of Grass Roots Social Activism in America 1921-1964. New York: Doubleday. Zingaro, L. (2009) Speaking Out: Storytelling for Social Change. Walnut Creek, CA: Left Coast Press Inc. 